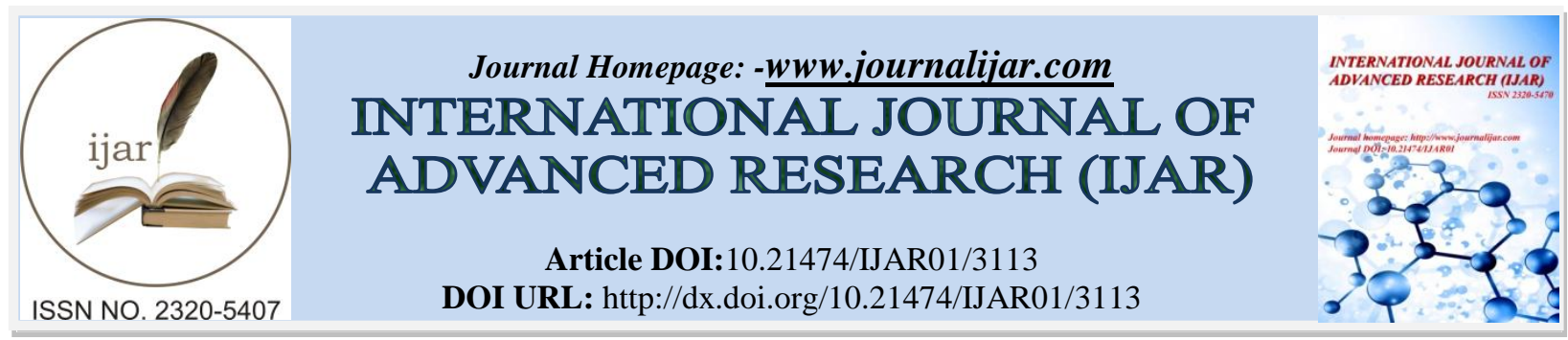

RESEARCH ARTICLE

\title{
DNA BARCODES OF THE PLECO (LORICARIIDAE, PTERYGOPLICHTHYS) IN THE CILIWUNG RIVER.
}

\section{Rosnaeni $^{1}$, Dewi Elfidasari ${ }^{1}$ and MeltaRini Fahmi ${ }^{2}$.}

1. Study Program of Biology, Faculty of Science and Technology, University of Al Azhar Indonesia.Kompleks Masjid Agung Al-Azhar, Jl. Singamangaraja, KebayoranBaru, Jakarta 12110, Indonesia.

2. Center for Research and Development of Ornamental Fish Aquaculture, Fisheries Research and Development Center, Ministry of Maritime Affairs and Fisheries. Jl. Perikanan No. 13 Pancoran Mas, Depok, West Java City 16436.

\section{Manuscript Info}

Manuscript History

Received: 01 December 2016

Final Accepted: 03 January 2017

Published: February 2017

\begin{abstract}
Pleco (Pterygoplichthys sp.) is an invasive freshwater species belong to LoricariidaeFamily and comes from Costa Rica, Panama, South America. Distribution of pleco spread throughout the freshwater of the world. One of the habitats in Indonesia is the Ciliwungriver and along the river with high abundance. Until now there has been no research results related to molecular identification of the fish especially from Ciliwung river. Therefore, it is necessary to know the molecular analysis of DNA to identify pleco from Ciliwungriver by using the technique of DNA barcoding gene CO1. The methodology consisted samples preparation, DNA extraction, DNA quantification, gene CO1 amplification, and DNA base sequence reading. Results identification using gene $\mathrm{CO} 1$ barcodes with a length of $650 \mathrm{bp}$ fragment showed that pleco from Ciliwung river has a $100 \%$ similarity with Pterygoplichthyspardalisspecies.There are transversion substitution nucleotide at nucleotide in positions $306(\mathrm{C} \rightarrow \mathrm{T}), 339(\mathrm{G} \rightarrow \mathrm{A}), 387$ $(\mathrm{C} \rightarrow \mathrm{T})$, and $471(\mathrm{~T} \rightarrow \mathrm{C})$, but this should not affect the amino acid sequence changes in pleco from Ciliwungriver.
\end{abstract}

Copy Right, IJAR, 2017,. All rights reserved.

\section{Introduction:-}

Background of the Study:-

Pleco(Pterygoplichthys sp.) is an invasive freshwater species including Family Loricariidae and comes from Costa Rica, Panama, and South America. Distribution of Plecospread from the tropic district until to Indo-Pacific (Yu \&Quailing 2014). The research result from Wu et al. (2011) states that there are three species of Plecoare most abundant in the world that is Pterygoplichthyspardalis, P. disjunctivus, P. multiradiatus. Two of these species are found in Indonesia, namely the species P.pardalis and $P$. disjunctivus.

The originate habitat Plecoare rivers, lakes and creeks (Nice et al. 2012). One river in Indonesia which becomes habitat PlecoisCiliwung river. According toRatmini (2009) Plecofound along the Ciliwung river with high abundance.

Corresponding Author:-Rosnaeni.

Address:-Study Program of Biology, Faculty of Science and Technology, University of Al Azhar Indonesia.Kompleks Masjid Agung Al-Azhar, Jl. Singamangaraja, KebayoranBaru, Jakarta 12110, 
The abundance of PlecoinCiliwung river for Plecohave a high level of adaptation in a polluted environment and the body of Plecocovered with plates of hard scales (Rachmatika\&Wahyudewantoro 2006). Therefore, Plecodidn'thave predators and be a competitor in obtaining food on the river ecosystem (Haiti 2007), so the species is considered to have contributed to decline in fish endemic ecosystem species Ciliwung river ecosystem (Kusumah 2011).

Results of Hadiaty research (2011) shows the data rate of loss the species endemicfromCiliwung river in2009 reached $92.5 \%$ of the initial number of about 187 species and decreased to 20 species, including five species of which is the introduction of fish species. This type of that fish is lost in the waters of the Ciliwungriver is betutu fish and Balidafish (Wowor 2010)

Morphological diversity and genetic information of an organism is very useful for the characterization of the type, the development, distribution by thetime and space. Characterization, development and distribution of populations are needed to determine the step of conservation, management and sustainable utilization. The level of diversity among the population, especially genetic diversity can be used as a step to estimate the level of risk of extinction and the abundance of an organism (Singkam et al., 2011). One of themethod to analyze the genetic diversity is molecular detection.

Molecular detection method was developed to analyze the genetic diversity of a species. Polymerase chain reaction (PCR) is a molecular detection method of in vitro without the use of living organisms to amplify a specific territory of a strand DNA. The reaction is limited by the primer pair (short oligonucleotide) using DNA polymerase enzyme and dNTPs as a number (Widowati 2013). The result of PCR is used to stage a reading strand bases in analyzing phylogenetic kinship.

One of the methods in tracing the phylogenetic relationships of a species commonly did is see the resemblance of mitochondrial DNA (mtDNA). Many studies related phylogenetic studies both invertebrate and vertebrate animals used mtDNA CO1 as the gene sign or genetic barcode (Maramis\&Warouw 2014). DNA barcoding is a molecular technique to identify species using differences in nucleotide sequence from standardized gene regions (Hubert et al. 2003). DNA barcoding is based on fragments of mtDNA gene Cytochrome Oxidase I (COI), which serves as a 'barcode' for identifying species (Ward et al., 2005).

CO1 genes of the mitochondrial genome are a gene that is often used as standard sign genes in animal identification. The superiority of $\mathrm{CO} 1$ gene is to have a universal primer solid, so as to identify the 5 'end from the most groups of animals. CO1 gene also has the highest molecular evolutionary compared with other genes in the mitochondria, thus having a low intraspecific variation and interspecific in height between adjacent taxa (Hajibabaei et al. 2006) Until now there has been no research results related molecular identification of the originate from of PlecoCiliwung river. Therefore it is necessary for the molecular analysis of DNA PlecofromCiliwungriveroriginate using DNA barcoding techniques.

\section{Objectives and Benefits Research:-}

This study was conducted to identify Pleco(Pterygoplichthys sp.) As a molecular marker gene CO1, knowing the genetic diversity, and the identification of changes in the nucleotide sequence Plecoin theCiliwung river Section of South Jakarta. The results are expected to be a source of information and databases for the genetic diversity of Pleco(Pterygoplichthys sp.) in the Ciliwungriver.

\section{Methodology:-}

The time and place of study:-

The study was conducted in August 2015-June 2016 include sampling of Plecoand molecular analysis. Sampling of Pleco conducted in August-November 2015 around Ciliwung of Rindam Jaya to Bidaracina (Figure 1). Furthermore, molecular analysis performed in March-June 2016 in the Laboratory of Genetics and Development Research Institute of Ornamental Fish Aquaculture, Ministry of Maritime Affairs and Fisheries, Depok. 


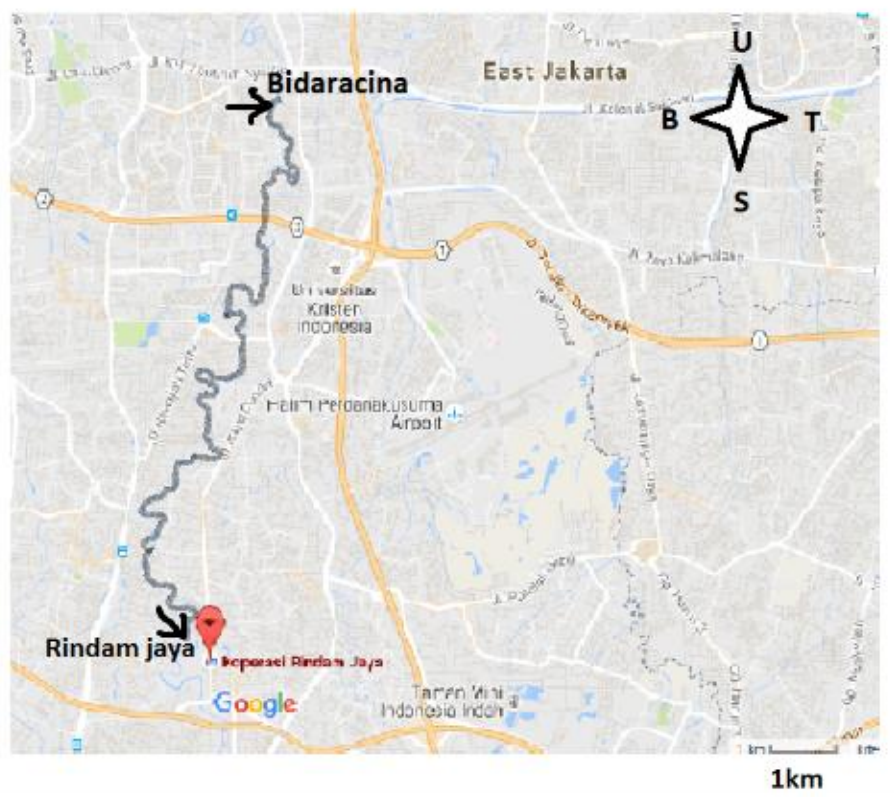

(Source: Google Maps)

Figure 1. Location of sampling of Rindam Jaya - Bidaracina

\section{Sample Preparation:-}

Decision fin muscle tissue as a source of DNA is done in Laboratory of Biology, University of Al Azhar Indonesia (UAI). The fins are used is the tip of the dorsal fin, pectoral and pelvic fins. Samples were cut using scissors and weighed $5-10 \mathrm{mg}$, then put into a $1.5 \mu \mathrm{L}$ micro-tubes containing $70 \%$ alcohol. Samples were then stored for 1-2 days before being moved into micro-tubes containing $1.5 \mu \mathrm{L}$ of absolute alcohol. Molecular analysis includes extraction, quantification, amplification, visualization, and the reading strand of DNA bases performed in the Laboratory of Genetics and Development Research Institute of Ornamental Fish Aquaculture, Ministry of Maritime Affairs and Fisheries, Depok.

\section{Extraction:-}

DNA extraction performed on 28 samples of fish using DNA GsyncGeneaideExraction kit. The extraction method followed the procedures issued by the company, involves the separation of the network, the destruction of cells, DNA binding, washing, and removal. Phase separation of the network is done by taking about 5-10 mg samples were cut into $1.5 \mu \mathrm{L}$ micro tube and then added $200 \mu \mathrm{L}$ GST Buffer and $20 \mu$ Lproteins K. Further samples of homogenized by vortex and incubated for 24 hours at a temperature of $60^{\circ} \mathrm{C}$.

Phase cell destruction is done after incubation of samples with the addition of $200 \mu \mathrm{L}$ GSB back Buffer and incubated for 20 minutes at a temperature of 200C. Further samples were centrifuged for $2 \mathrm{~min}$ at $15000 \mathrm{~g}$ to separate the supernatant with pellets. Supernatant is taken and separated into a new micro tube.

The next stage is the binding of DNA by adding $200 \mu \mathrm{L}$ of absolute alcohol in the supernatant and homogenized. Samples were then transferred on columntube $2 \mathrm{~mL}$ and the collecting tube which then centrifuged at $15000 \mathrm{~g}$ for 1 minute. The liquidsolutioncolumn tubedisposedand then collecting tube was transferred to a new tube.

Washing stage by adding $400 \mu \mathrm{L}$ of Wash Bufferin 1 coloumn tube and centrifuged at $15,000 \mathrm{~g}$ for 30 seconds. The solution liquid to the collecting tube was removed and reassembled. For the drying process is done centrifugation at $15,000 \mathrm{~g}$ for $3 \mathrm{~min}$. Coloumn phase of displacement by moving the tube into a new micro tube and added 100 $\mu \mathrm{LN}$ uclease Free Water (NFW) that has been heated at $60^{\circ} \mathrm{C}$ after that silenced for the last 3 minutes and centrifuged at $15,000 \mathrm{~g}$ for 30 seconds to get the DNA. 


\section{Quantification of DNA:-}

DNA quantification is done using a spectrophotometer Gene Quant with standard volume of $80 \mu \mathrm{L}$ NFW containing $2 \mu \mathrm{L}$ of sample DNA extraction results.

\section{DNA amplification:-}

Fish amplification using the primers F1 (51- TCA - ACC - AAC - CAC - AAA - GAC - ATT - GGC - AC -31) and R1 (51- TAG - ACT - TCT - GGG - TGG - CCA - AAG - AAA - TCA -31) (Ward et al., 2005).

Table 1:- The PCR program

\begin{tabular}{|l|l|l|}
\hline Step & Temperature $\left({ }^{0} \mathbf{C}\right)$ & Time \\
\hline Inisiasi & 94 & 5 second \\
\hline Denaturasi & 94 & 30 second \\
\hline Anneling & 52 & 30 second \\
\hline Elongasi & 72 & 30 second \\
\hline Post-elongasi & 72 & 5 second \\
\hline
\end{tabular}

The PCR process is carried out as many as 35 cycles. Components PCR $50 \mu \mathrm{L}$ consists of nuclease free water (NFW) as much as $11 \mu \mathrm{L}$, forward primer F1 and revers R1 respectively of $2 \mu \mathrm{L}$, master mix $25 \mu \mathrm{L}$ (containing dNTP, buffer and taq polymerase), and the DNA samples of $10 \mu \mathrm{L}$,

\section{Visualization:-}

Visualization of DNA using agarose gel (1.5\%) with peq green dyes DNA and RNA dye. The result of extraction with the addition of loading dye was electrophoreses in $1 \mu \mathrm{L}$ and a DNA sample as much $5 \mu \mathrm{L}$. Electrophoresis was performed on the current strength of 100 volts for 30 minutes and then photographed using a gel doc with UV rays of a wavelength of $302 \mathrm{~nm}$.

\section{Readings strand bases|:-}

Readings strand bases conducted on 13 samples from 28 samples are amplified namely with sample numbers 6, 7, 9, $13,15,17,20,21,22,24,25,26$, and 28. Selection of sequencing refers to the pattern of the abdomen. The pattern of abdominal Pleco fish in the study were classified into three ( $\mathrm{A}=$ black spots, $\mathrm{B}=$ lines are not interrupted, and $\mathrm{C}$ $=\mathrm{a}$ combination of the pattern of black spots and black lines).

Readings base strand done using ABI'S Sequens Scanner. Sequencing the form of DNA sequences which are then read and analyzed using MEGA 7.0.Further aligned with the access number listed in the NCBI GenBank by BLAST to obtain the identification of the species of the sample (Maramis\&Warouw 2014).

\section{Results And Discussion:-}

The concentration and purity of DNA Fish Pleco fishoriginate fromCiliwung River:-

The results of the measurement of DNA concentration of fish samples ranged between 36-484 $\mathrm{ng} / \mu \mathrm{L}$ and purity index value (A260 / A280) on average is worth 1.96 (Appendix 1). DNA concentration is the number of DNA (pg) in the sample $(\mu \mathrm{L})$. The number of DNA concentration in a sample is determined by the activity of organ samples and expressing certain genes in an organ (Tiara et al. 2014). DNA purity is a purity level of DNA samples obtained from the A260 / A280 (Sambrook and Russell 2001).

Measurement of DNA concentration using a Gene-Quant has a principle wavelength spectrophotometer with $260 \lambda$. A beam of UV light passed through a sample of a specific wavelength to see the purity and concentration of DNA. This is done to measure the purity, DNA concentration, protein concentration, and absorbance. Absorbance value is the value measured using a wavelength of 260 , so that the absorbance value is the reference number of the DNA concentration (Tiara et al. 2014).

Extraction of DNA can be obtained from muscle tissue and blood. Muscles on the fins are a system of organs that have a central role in the movement of fish. Striated muscle groups are named according to the place of attachment, such as enforcement muscle dorsal fin and pectoral fins towing muscle (Rahardjo et al. 2010). The use of fin muscle tissue as a source of the DNA showed that the muscle tissue of fish fins Pleco fish can be a good source of DNA for molecular analysis. 
Based on one way ANOVA statistical test showed that the source of the DNA of the dorsal fin, pectoral and pelvic fins have DNA purity values were not significantly different (Figure 2). Significance probability value of 0541 which means> 0.05 showed no significant difference between types of fins are used as a source of DNA (Appendix 2). According to Newson (2013) if the significance value of $<0.05$ means that there are significant differences among the treatments.

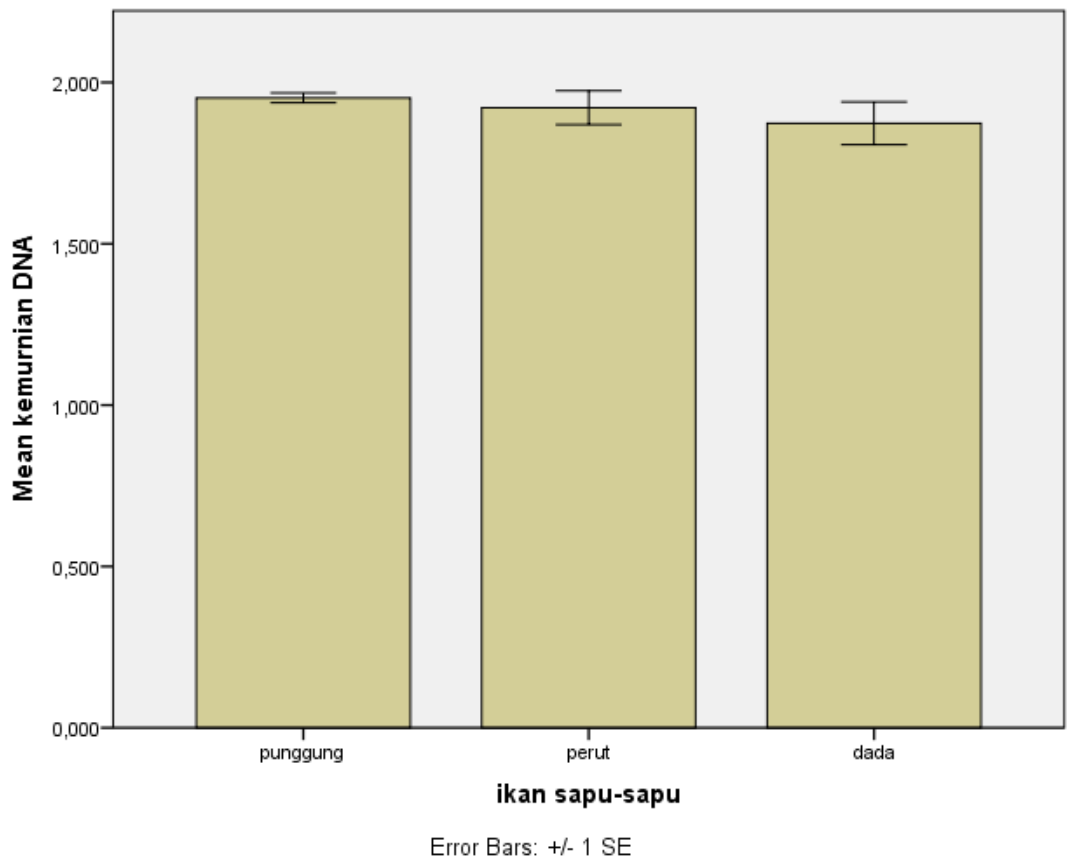

Figure 2:- The average value of purity DNA from several types of fins

DNA purity Pleco fishoriginate from Ciliwung river has a value of purity (A260 / A280) an average of 1.9 so that it can be expressed as pure DNA. DNA is said to be pure if it has a purity index of 1.8 to 2.2 (Aryahiyyah 2014; Wardani\& Sari 2015). DNA which has a purity value of less than 1.8 indicate the presence of protein contamination, and if the DNA has a purity value of more than 2.0 indicate contamination of RNA. This can occur because of the absence of additional RNase enzyme that works to degrade RNA. Protein contamination can be caused by lack of protein degradation in the washing step (Aryahiyyah 2014). In the process of isolation of DNA, protein is a contaminant that must be degraded (Sambrook\&Russel 2001).

\section{Visualization the Results of DNA ExtractionPlecooriginate fromCiliwungriver:-}

Visualization of the extracted DNA Pleco fish on a 1.5\% agarose gel shows that DNA can be clearly seen (Figure 3). This is consistent with the concentration and purity of DNA was good so the quality of the electrophoresis results is clearly visible on a $1.5 \%$ agarose gel. Electrophoresis using a marker size of $100 \mathrm{bp}$.

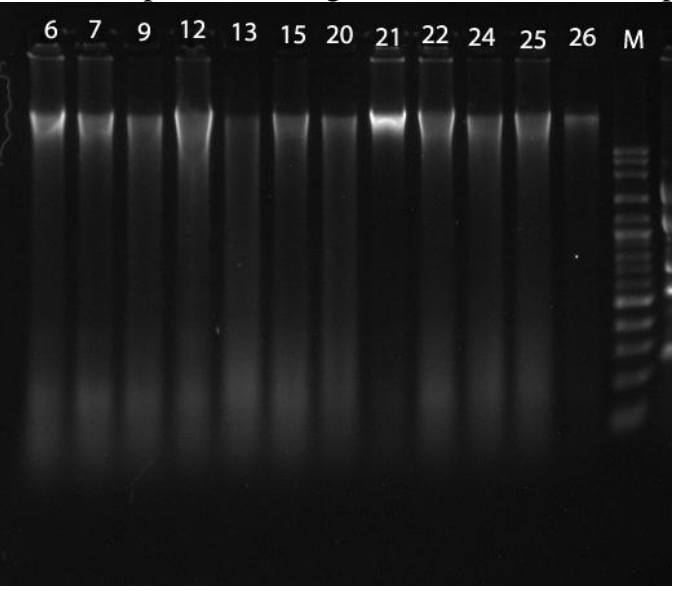


Figure 3:- Results of DNA extraction Pleco fish(M = Marker; 6,7,9,12,13,15,20,21,22,24,25,26 = No. Sample fish) Electrophoresis is the movement of electrically charged substances due to the influence of an electric field (Wardani\& Sari 2015). DNA molecules including negatively charged compounds so that the process of electrophoresis, DNA migrate toward the positive pole. DNA molecule migration velocity depends on the concentration of the gel used, the size of the molecules being analyzed, as well as the power supply voltage is supplied. Agarose gel used to separate, identify, and purify DNA fragments. The movement of DNA fragments in agarose gels is strongly influenced by the composition and solubility of the ion electrophoresis buffer. If the concentration of ions is very little the electrical conductivity is very small and DNA migration becomes slow. Excessive ion concentration will result in the gel melts and denatured DNA. DNA electrophoresis technique also requires loading buffer. This buffer works to increase the sample density that is at the bottom well and gives color to the DNA fragment to facilitate observation of the process of electrophoresis (Sambrook\&Russel 2001).

\section{CO1 gene amplification Fish Pleco fishoriginate fromCiliwungRiver:-}

CO1 gene amplification product Pleco fishoriginate fromCiliwungRiver is clearly visible on a $1.5 \%$ agarose gel. This indicates that the Primer F1 and R1 successfully amplify the COI gene Pleco fishfishoriginate fromCiliwungRiver in fragment length of $650 \mathrm{bp}$ (Figure 4).

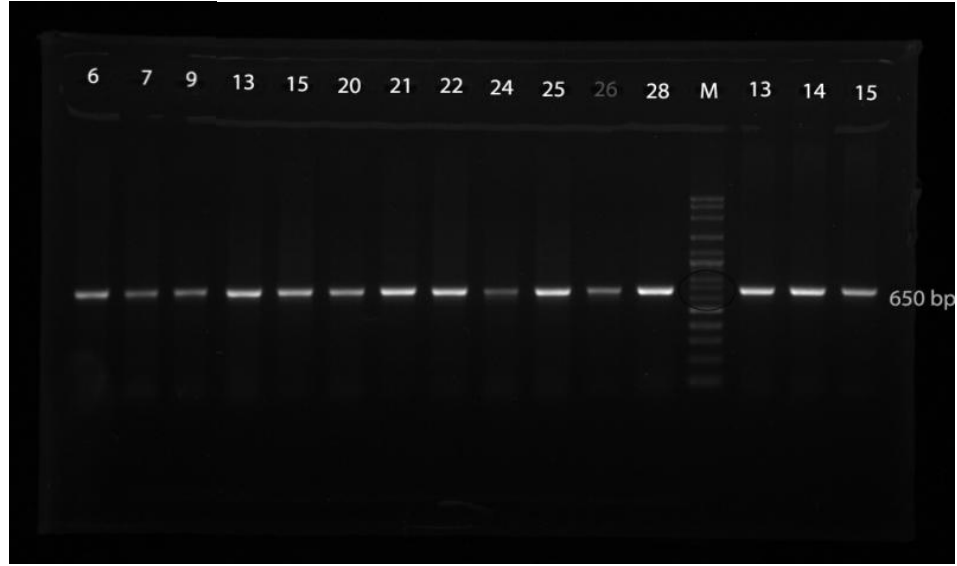

Figure 4. Results of CO1 gene amplification Pleco fish(M = Marker; 13,14,15 = positive control; $6,7,9,13,15,20,21,22,24,25,26,28=$ No . Samples of Pleco fish fromCiliwungriveroriginate)

F1 primer and R1 have managed to amplify the gene CO1 Pleco fish with long 615 bp fragment (Yu \&Quilang 2014). In research Jumawan et al. (2011) F1 primer and R1 succeeded in amplifying the gene CO1 Pleco fish with long fragment of $650 \mathrm{bp}$. Research Bijukumar et al. (2015) using the primers F1 and R1 CO1 gene amplification produces fish with long Pleco fish 565 bp fragment. Hajibabaei\& McKenna (2012) states that the gene CO1 barcodes can be done with a length of 454-650 bp fragment of $650 \mathrm{bp}$ and a total length of CO1 gene fragment for DNA barcoding.

\section{CO1 gene readout strand BasaPleco fishoriginate fromCiliwungRiver:-}

Based on the reading strand of the COI gene base 13 fish samples Pleco fishCiliwungriveroriginate from obtained sequences with a length of 680 bp fragment (Figure 5). According Hajibabaei et al. (2007) Long sequences are still within the limits of the standard barcode for animals.

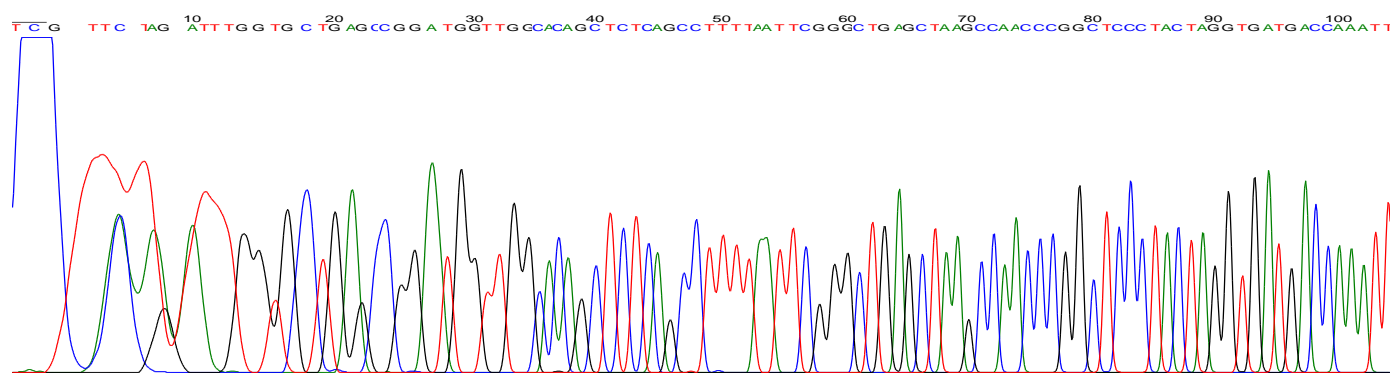




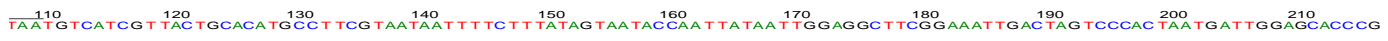
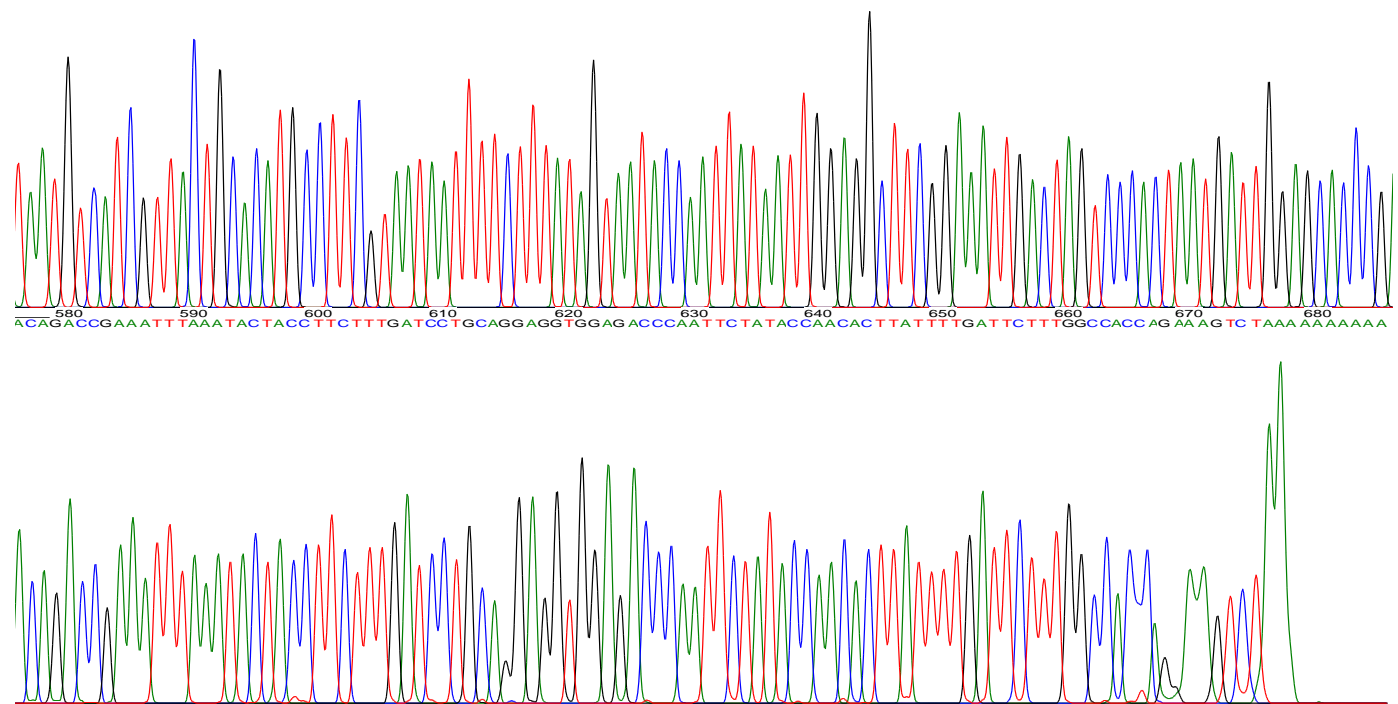

Figure 5:- Ektogram reading strand of DNA bases Pleco fishoriginate fromCiliwungriver before cutting (680 bp)

The nucleotide sequences of 13 samples of Pleco fishoriginate fromCiliwungRiver then compared with the nucleotide sequences in GenBank NCBI (National Center for Biotechnology Information). It aims to determine the similarity of the reading strand fragments to the data base GenBank using BLAST (Basic Local Alignment Search Tool) on megablast-high similarity (Table 3).

Table 2. Comparison of similarity between the base strand 13 fish samples Pleco fishoriginate fromCiliwungriver with NCBI GenBank Data

\begin{tabular}{|l|l|l|l|l|}
\hline No. & Code Pleco & Identities (\%) & Data Base genbank & Code genbank \\
\hline 1 & CIL 017-A & $100 \%$ & Pterygoplichthys pardalis & JF769358.1 \\
\hline 2 & CIL 007-C & $100 \%$ & Pterygoplichthys pardalis & JF769358.1 \\
\hline 3 & CIL 013-C & $100 \%$ & Pterygoplichthys pardalis & JF769358.1 \\
\hline 4 & CIL 026-C & $100 \%$ & Pterygoplichthys pardalis & JF769358.1 \\
\hline 5 & CIL 028-B & $100 \%$ & Pterygoplichthys pardalis & JF769357.1 \\
\hline 6 & CIL 025-C & $100 \%$ & Pterygoplichthys pardalis & JF769357.1 \\
\hline 7 & CIL 024-C & $100 \%$ & Pterygoplichthys pardalis & JF769357.1 \\
\hline 8 & CIL 022-A & $100 \%$ & Pterygoplichthys pardalis & JF769357.1 \\
\hline 9 & CIL 021-C & $100 \%$ & Pterygoplichthys pardalis & JF769357.1 \\
\hline 10 & CIL 020-C & $100 \%$ & Pterygoplichthys pardalis & JF769357.1 \\
\hline 11 & CIL 015-A & $100 \%$ & Pterygoplichthys pardalis & JF769357.1 \\
\hline 12 & CIL 009-B & $100 \%$ & Pterygoplichthys pardalis & JF769357.1 \\
\hline 13 & CIL 006-C & $100 \%$ & Pterygoplichthys pardalis & JF769357.1 \\
\hline
\end{tabular}

Results blast on NCBI genbank indicates that nucleotide sequence Pleco fishoriginate fromCiliwungriver showed an average value of $100 \%$ identification accuracy with Pterygoplichthys pardalis species (Table 3). This suggests that the originate from of the Pleco fish from Ciliwung river is one species. Hubert et al. (2003) similarity of identity with an average of $97 \%$ shows the same species.

Research Bijukumar et al. (2015), Yu \&Quilang (2014) and Jumawan et al. (2011) phylogenetic similarity identity Pleco fish showed the same up to $100 \%$, so that the $\mathrm{CO} 1$ gene can produce a high resolution for identification of the species as a standard barcode. According to Yu and Quilang (2014) the species P. Pardalis and P. disjunctivus is probably the same species or synonyms and have a low genetic diversity. Distinguishing morphological characters are dark lines continuously on P.disjunctivus, whereas in P. pardalishave dark spots (Chavez et al. 2006). Research Bijukumar et al. (2015) shows the similarity of $100 \%$ and $0 \%$ genetic distance between species P. pardalis, $P$. disjunctivus and P.ambrosetti. These results suggest that differences in the pattern of the abdomen is not the main character to identify fish species Pleco fish. 


\section{Variations Nucleotide and Amino Acid Fish Pleco fishoriginate fromCiliwungRiver:-}

The composition of the nucleotide Pleco fishoriginate fromCiliwung river is $\mathrm{A}=26.23 \%, \mathrm{~T} / \mathrm{U}=30.60 \%, \mathrm{C}=$ $26.18 \%$, and $\mathrm{G}=16.99 \%$. For the process of translation into amino acids ururan cutting $11 \mathrm{bp}$ fragment or to find the start codon AUG (ATG). After cutting with a nucleotide variation obtained nucleotide fragment length $653 \mathrm{bp}$. Furthermore nucleotide positions can be analyzed to determine the location of the transition and tranversi substitution. There transversion nucleotide substitution in fish samples Pleco fishoriginate fromCiliwung river as much as 4 points namely to nucleotide position $306(\mathrm{C} \rightarrow \mathrm{T}), 339(\mathrm{G} \rightarrow \mathrm{A}), 387(\mathrm{C} \rightarrow \mathrm{T})$, and $471(\mathrm{~T} \rightarrow \mathrm{C})(\mathrm{Figure} 6)$.

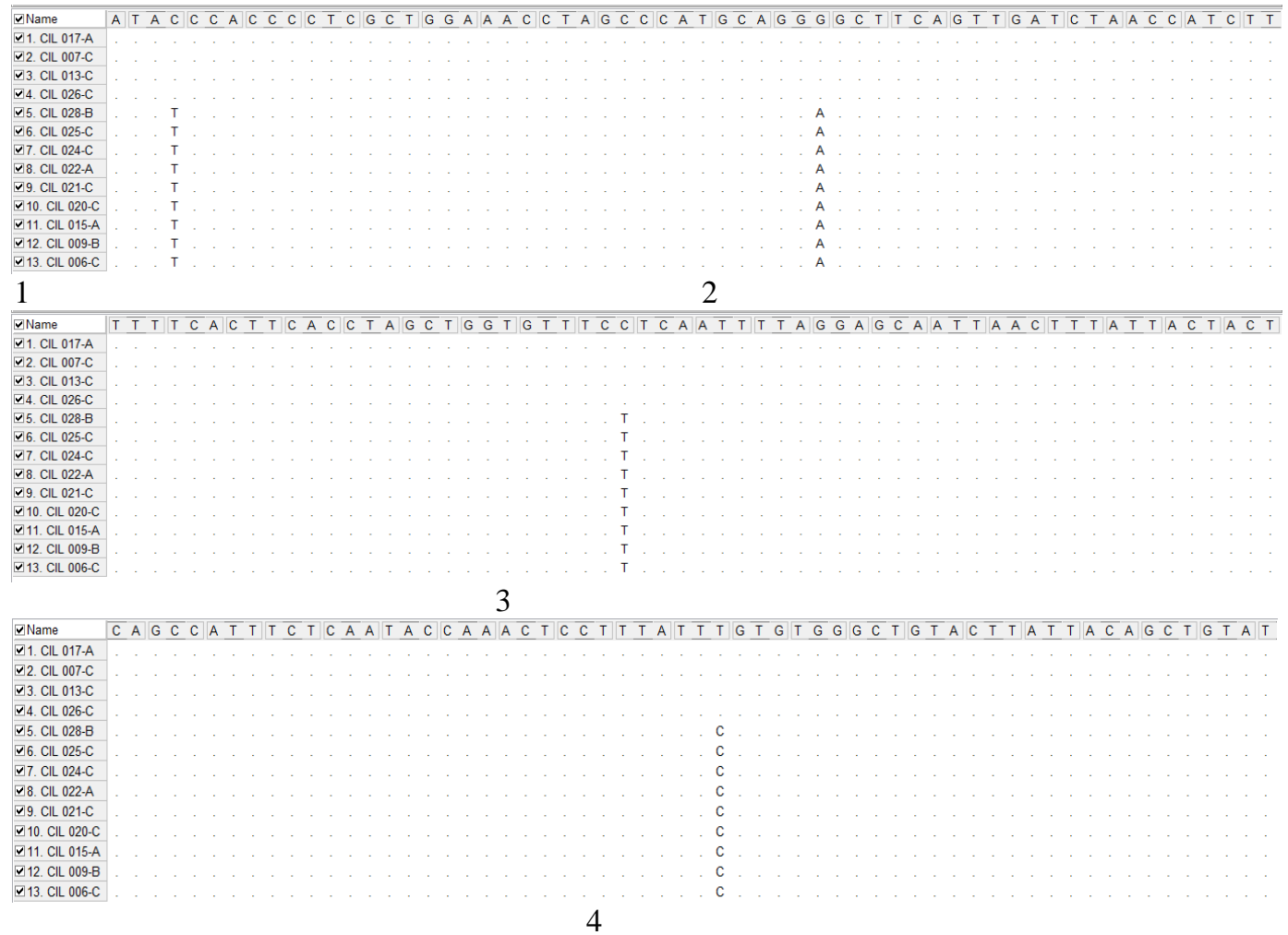

Figure 6:- Variations in the nucleotide composition and changes in nucleotide variations Pleco fish originate fromCiliwung river $(1=$ position information to the nucleotide-306, $2=$ position of nucleotides to $339,3=$ to the nucleotide position $387,4=$ all nucleotide position 471 )

The analysis shows that there are different variations of the arrangement of nucleotides in Pleco fishoriginate fromCiliwungriver. Differences in the nucleotide arrangement causes the Pleco fishoriginate fromCiliwung river splits into two on the construction of phylogenetic clade (Figure 7). Therefore, the fourth point of nucleotides serves as the main characteristics of each clade and distinguishing nucleotide sequences between individuals. Ubaidilah and Sutrisno (2009) states that if the DNA sequence emerges from a common ancestor sequence, the sequence will gradually separate offspring through nucleotide differences due to mutations or point mutations.

Nucleotide sequence variation along the 653 bpPlecofishoriginate fromCiliwung river ported 217 amino acid sequences. Changes nucleotide variation on four nucleotide positions $(306,339$, 387, and 471) did not affect the changes of amino acid variation. Nucleotide variation occurs in nucleotide position to 306 (TAC $\rightarrow$ TAT) which translations the amino acid position $102(\mathrm{Y})$ that is Tyrosine, all nucleotide position 339 (GGG $\rightarrow$ GGA) translates to the amino acid position $113(\mathrm{G})$ is Glycine, to nucleotide position 387 (TCC $\rightarrow$ TCT) translates to the amino acid position 129 (S) is Serine, and all nucleotide position 471 (TTT $\rightarrow$ TTC) translations the amino acid position 157 (F) is Phenylalanine (Appendix 3 ).

Changes in the nucleotide variation four positions do not change the amino acid sequence translated. According to Lynch and Jaryl (1993) amino acid sequence changes occur more slowly in CO1 gene so that accuracy in phylogenetic. The substitution of base pairs (base-pair substitution) is the turn of one nucleotide and partner with 
another pair of nucleotides. Some substitution called silent mutations (silent mutation) from an excess of genetic code. Thats not influental the amino acid sequence translated. In other words, nucleotide mutations do not change the amino acid translation of the same. Some codons can translate the same amino acids if there is a difference in the third base of the triplet codon (Campbell et al., 2008), as in the TTT and TTC codon that translates the same amino acid that is Phenilalanine (F).

\section{Construction Phylogenetic Fish Sweep broom:-}

The results of phylogenetic construction Pleco fishoriginate fromCiliwungriver and out group genus Synodontis (Synodontisdecoratus, S.euterus, and S.leopard) showed genetic distance apart. Plecofishoriginate fromCiliwung river is divided into two clade this is due to changes in the four nucleotide variations (Figure 7).

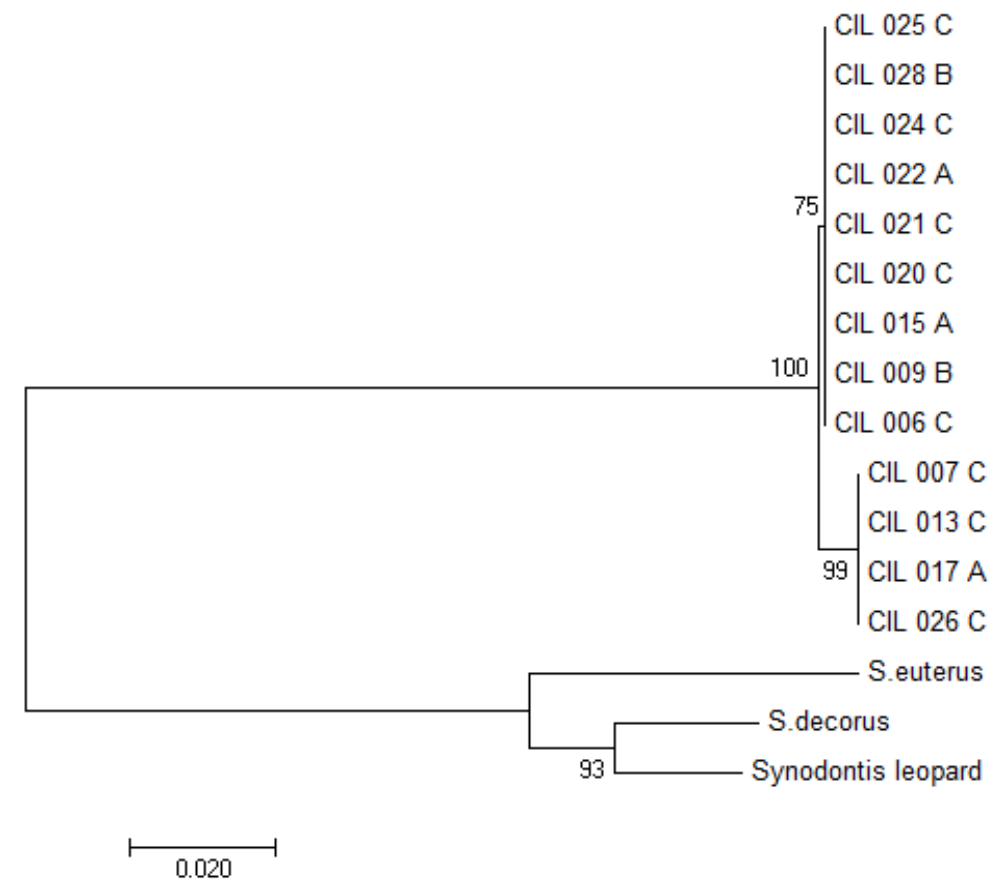

Figure 7. Construction of phylogenetic Pleco fish originate fromCiliwungriver with NJ-boostrap 1000x (649 bp) According Mahardika and Parede (2008) the method most commonly used method is the Neighbor-Joining (NJ). The branching pattern of phylogenetic tree based on the distance matrix is formed between the pair populations. Long branches of the phylogenetic tree describes the number of nucleotide substitutions in the form of DNA polymorphism. Skala is located under a phylogenetic tree showing the size of the distance between sequences. Numbers located on the branches of the phylogenetic tree shows the value boostrap (Mahardika\&Parede 2008). Bootstrap value in fish samples Pleco fish showed a value of $100 \%$. Bootstrap analysis was conducted to test the validity of the construction of phylogenetic trees. Phylogenetic trees giving information about the classification of the population based on evolutionary relationships. In the reconstruction of phylogenetic trees, the molecular data more widely used because it is considered more stable in the process of evolution compared with the morphological data (Dharmayanti 2011). 


\begin{tabular}{|c|c|c|c|c|c|c|c|c|c|c|c|c|c|c|c|c|}
\hline & 1 & 2 & 3 & 4 & 5 & 6 & 7 & 8 & 9 & 10 & 11 & 12 & 13 & 14 & 15 & 16 \\
\hline 1. CIL 017_A & & 0.000 & 0.000 & 0.000 & 0.003 & 0.003 & 0.003 & 0.003 & 0.003 & 0.003 & 0.003 & 0.003 & 0.003 & 0.020 & 0.021 & 0.022 \\
\hline 2. CIL 007_C & -0.000 & & 0.000 & 0.000 & 0.003 & 0.003 & 0.003 & 0.003 & 0.003 & 0.003 & 0.003 & 0.003 & 0.003 & 0.020 & 0.021 & 0.022 \\
\hline 3. CIL 013 C & -0.000 & -0.000 & & 0.000 & 0.003 & 0.003 & 0.003 & 0.003 & 0.003 & 0.003 & 0.003 & 0.003 & 0.003 & 0.020 & 0.021 & 0.022 \\
\hline 4. CIL 026_C & -0.000 & -0.000 & -0.000 & & 0.003 & 0.003 & 0.003 & 0.003 & 0.003 & 0.003 & 0.003 & 0.003 & 0.003 & 0.020 & 0.021 & 0.022 \\
\hline 5. CIL 028_B & 0.006 & 0.006 & 0.006 & 0.006 & & 0.000 & 0.000 & 0.000 & 0.000 & 0.000 & 0.000 & 0.000 & 0.000 & 0.020 & 0.020 & 0.022 \\
\hline 6. CIL 025 _C & 0.006 & 0.006 & 0.006 & 0.006 & -0.000 & & 0.000 & 0.000 & 0.000 & 0.000 & 0.000 & 0.000 & 0.000 & 0.020 & 0.020 & 0.022 \\
\hline 7. CIL 024_C & 0.006 & 0.006 & 0.006 & 0.006 & -0.000 & -0.000 & & 0.000 & 0.000 & 0.000 & 0.000 & 0.000 & 0.000 & 0.020 & 0.020 & 0.022 \\
\hline 8. CIL 022_A & 0.006 & 0.006 & 0.006 & 0.006 & -0.000 & -0.000 & -0.000 & & 0.000 & 0.000 & 0.000 & 0.000 & 0.000 & 0.020 & 0.020 & 0.022 \\
\hline 9. CIL 021_C & 0.006 & 0.006 & 0.006 & 0.006 & -0.000 & -0.000 & -0.000 & -0.000 & & 0.000 & 0.000 & 0.000 & 0.000 & 0.020 & 0.020 & 0.022 \\
\hline 10. CIL 020_C & 0.006 & 0.006 & 0.006 & 0.006 & -0.000 & -0.000 & -0.000 & -0.000 & -0.000 & & 0.000 & 0.000 & 0.000 & 0.020 & 0.020 & 0.022 \\
\hline 11. CIL 015_A & 0.006 & 0.006 & 0.006 & 0.006 & -0.000 & -0.000 & -0.000 & -0.000 & -0.000 & -0.000 & & 0.000 & 0.000 & 0.020 & 0.020 & 0.022 \\
\hline 12. CIL 009_B & 0.006 & 0.006 & 0.006 & 0.006 & -0.000 & -0.000 & -0.000 & -0.000 & -0.000 & -0.000 & -0.000 & & 0.000 & 0.020 & 0.020 & 0.022 \\
\hline 13. CIL $006 \_C$ & 0.006 & 0.006 & 0.006 & 0.006 & -0.000 & -0.000 & -0.000 & -0.000 & -0.000 & -0.000 & -0.000 & -0.000 & & 0.020 & 0.020 & 0.022 \\
\hline 14. Synodontis leopard & 0.214 & 0.214 & 0.214 & 0.214 & 0.208 & 0.208 & 0.208 & 0.208 & 0.208 & 0.208 & 0.208 & 0.208 & 0.208 & & 0.008 & 0.011 \\
\hline 15. S.decorus & 0.217 & 0.217 & 0.217 & 0.217 & 0.210 & 0.210 & 0.210 & 0.210 & 0.210 & 0.210 & 0.210 & 0.210 & 0.210 & 0.037 & & 0.011 \\
\hline 16. S.euterus & 0.227 & 0.227 & 0.227 & 0.227 & 0.225 & 0.225 & 0.225 & 0.225 & 0.225 & 0.225 & 0.225 & 0.225 & 0.225 & 0.075 & 0.076 & \\
\hline
\end{tabular}

Figure 8. Construction of fish genetic distance Pleco fishoriginate fromCiliwungriver

Fish genetic distance Pleco fishoriginate fromCiliwung river is 0.0-0.03 (Figure 8). This suggests that the genetic distance were lower in Pleco fishoriginate fromCiliwungriver, so the Pleco fishoriginate fromCiliwung river is the same species. According to Hebert et al. (2004) and Ward et al. (2009) said that the genetic distance of more than 0:03 can show different types. This is evident with the genetic distance Pleco fishoriginate fromCiliwung river with out group genus Synodontis has a genetic distance of 0:18 to 0:20 (Figure 10).

\section{Conclusion:-}

Pleco fishoriginate fromCiliwung river had been identified using DNA barcodes CO1 on a fragment length of 650 bp. The nucleotide sequences Pleco fish aligned on NCBI genbank showed an average value of $100 \%$ identification accuracy with Pterygoplichthyspardalis species. There transversion nucleotide substitution at nucleotide position to $306(\mathrm{C} \rightarrow \mathrm{T}), 339(\mathrm{G} \rightarrow \mathrm{A}), 387(\mathrm{C} \rightarrow \mathrm{T})$, and $471(\mathrm{~T} \rightarrow \mathrm{C})$, but this should not affect the amino acid sequence changes in Pleco-baby fish originate fromCiliwung river.

Appendix 1. The concentration and purity of the fish DNA Pleco fishoriginate fromCiliwung River.

Sample Concentration of DNA purity (A260 / A280)

\begin{tabular}{|l|l|l|}
\hline Sample & Contretation of DNA & Purity (A260/A280) \\
\hline 1 & 54 & 1,929 \\
\hline 2 & 274 & 2,015 \\
\hline 3 & 480 & 1,9 \\
\hline 4 & 246 & 1,952 \\
\hline 5 & 398 & 1,932 \\
\hline 6 & 168 & 2,049 \\
\hline 7 & 228 & 1,966 \\
\hline 8 & 484 & 1,906 \\
\hline 9 & 164 & 2,05 \\
\hline 10 & 160 & 1,633 \\
\hline 11 & 268 & 1,971 \\
\hline 12 & 320 & 2 \\
\hline 13 & 228 & 2 \\
\hline 14 & 374 & 1,928 \\
\hline 15 & 190 & 1,979 \\
\hline 16 & 190 & 1,9 \\
\hline 17 & 308 & 1,901 \\
\hline 18 & 170 & 1,809 \\
\hline 19 & 210 & 1,842 \\
\hline 20 & 154 & 2,026 \\
\hline 21 & 114 & 1,9 \\
\hline 22 & 236 & 2 \\
\hline 23 & 68 & 2 \\
\hline & & \\
\hline & & \\
\hline
\end{tabular}




\begin{tabular}{|l|l|l|}
\hline 24 & 152 & 2 \\
\hline 25 & 210 & 1,981 \\
\hline 26 & 36 & 2,25 \\
\hline 27 & 206 & 1,981 \\
\hline 28 & 176 & 2,095 \\
\hline Rata-rata & $\mathbf{1 , 9 6 0 5 3 5 7 1 4}$ \\
\hline
\end{tabular}

Appendix 2:- The results of the analysis of DNA purity Plecofishoriginate fromCiliwung River

ANOVA

kemurnian DNA

\begin{tabular}{|l|r|r|r|r|r|}
\hline & $\begin{array}{c}\text { Sum of } \\
\text { Squares }\end{array}$ & df & Mean Square & F & Sig. \\
\hline Between Groups &, 022 & 2 &, 011 &, 636 &, 541 \\
Within Groups &, 311 & 18 &, 017 & & \\
Total &, 333 & 20 & & & \\
\hline
\end{tabular}

Appendix 3:- Variations in the nucleotide and amino acid Plecooriginate fromCiliwung

\begin{tabular}{|c|c|c|c|c|c|c|c|c|c|c|c|c|c|}
\hline$\checkmark$ Name & $T$ & G & $\mathrm{T}$ & A & $T$ & A & C & C & C & A & C & C & c \\
\hline$\nabla 1$. CIL 017-A & & & & & & & & & & & & & \\
\hline จ2. CIL 007-C & & & & & & & & & & & & & \\
\hline v3. CIL 013-C & . & & & & & & & & & & & & \\
\hline$\nabla 4 . \mathrm{CIL} 026-\mathrm{C}$ & - & & & & & & & & & & & & \\
\hline$\nabla 5$. CIL 028-B & - & & & & & & $T$ & & & & & & \\
\hline$\checkmark 6 . \mathrm{CIL} 025-\mathrm{C}$ & . & & & & & & T & & & & & & \\
\hline$\nabla 7$. CIL 024-C & . & & & & & & T & & & & & & \\
\hline$\checkmark 8$. CIL 022-A & - & & & & & & T & & & & & & \\
\hline$\nabla 9 . \mathrm{CIL} 021-\mathrm{C}$ & - & & & & & & T & & & & & & \\
\hline$\nabla 10 . \mathrm{ClL} 020-\mathrm{C}$ & . & & & & & & T & & & & & & \\
\hline$\checkmark 11 . \mathrm{CIL}$ 015-A & . & & & & & & $\mathrm{T}$ & & & & & & \\
\hline$\nabla 12$ CIL 009-B & - & & & & & & T & & & & & & \\
\hline$\checkmark 13 . \mathrm{CIL} \mathrm{006-C}$ & - & & & & & & $\mathrm{T}$ & & & & & & \\
\hline \\
\hline $306 / 653$ & & & & ghlic & ghte & & None & & & & & & Data \\
\hline
\end{tabular}

\begin{tabular}{|c|c|c|c|c|c|c|c|c|c|c|}
\hline \multicolumn{11}{|l|}{$\square$ Name } \\
\hline$\checkmark 1$. CIL 017-A & $\mathrm{T}$ & v & Y & $P$ & $\mathrm{P}$ & L & A & G & $\mathrm{N}$ & $\mathrm{L}$ \\
\hline च2. CIL 007-C & $\mathrm{T}$ & V & Y & $\mathrm{P}$ & $\mathrm{P}$ & $\mathrm{L}$ & A & G & $\mathrm{N}$ & $\mathrm{L}$ \\
\hline च3. CIL 013-C & $\mathrm{T}$ & V & Y & $\mathrm{P}$ & $\mathrm{P}$ & $\mathrm{L}$ & A & G & $\mathrm{N}$ & L \\
\hline$\checkmark 4 . \mathrm{CIL} 026-\mathrm{C}$ & $\mathrm{T}$ & $\mathrm{V}$ & Y & $\mathrm{P}$ & $\mathrm{P}$ & $\mathrm{L}$ & A & G & $\mathrm{N}$ & $\mathrm{L}$ \\
\hline च5. CIL 028-B & $\mathrm{T}$ & V & Y & $\mathrm{P}$ & $\mathrm{P}$ & $\mathrm{L}$ & A & G & $\mathrm{N}$ & $\mathrm{L}$ \\
\hline च6. CIL 025-C & $\mathrm{T}$ & v & Y & $\mathrm{P}$ & $\mathrm{P}$ & $\mathrm{L}$ & A & G & $\mathrm{N}$ & $\mathrm{L}$ \\
\hline च7. CIL 024-C & $\mathrm{T}$ & $\mathrm{V}$ & Y & $\mathrm{P}$ & $\mathrm{P}$ & $\mathrm{L}$ & A & G & $\mathrm{N}$ & $\mathrm{L}$ \\
\hline$\nabla 8 . \mathrm{CIL} 022-\mathrm{A}$ & $\mathrm{T}$ & V & Y & $\mathrm{P}$ & $\mathrm{P}$ & $\mathrm{L}$ & A & G & $\mathrm{N}$ & $\mathrm{L}$ \\
\hline च9. CIL 021-C & $\mathrm{T}$ & v & Y & $\mathrm{P}$ & $\mathrm{P}$ & $\mathrm{L}$ & A & G & $\mathrm{N}$ & L \\
\hline$\checkmark 10 . \mathrm{CIL} \mathrm{020-C}$ & $\mathrm{T}$ & V & Y & $\mathrm{P}$ & $\mathrm{P}$ & $\mathrm{L}$ & A & G & $\mathrm{N}$ & $\mathrm{L}$ \\
\hline च11. CIL 015-A & $\mathrm{T}$ & $\mathrm{v}$ & Y & $\mathrm{P}$ & $\mathrm{P}$ & $\mathrm{L}$ & A & G & $\mathrm{N}$ & L \\
\hline च12. ClL 009-B & $\mathrm{T}$ & V & $\mathrm{Y}$ & $\mathrm{P}$ & $\mathrm{P}$ & $\mathrm{L}$ & A & G & $\mathrm{N}$ & L \\
\hline$\checkmark 13 . \mathrm{CIL} \mathrm{006-C}$ & $\mathrm{T}$ & $\mathrm{V}$ & $\mathrm{Y}$ & $\mathrm{P}$ & $\mathrm{P}$ & $\mathrm{L}$ & A & G & $\mathrm{N}$ & $\mathrm{L}$ \\
\hline \multicolumn{11}{|l|}{ 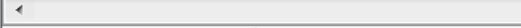 } \\
\hline \multicolumn{3}{|c|}{$304,305,306[102 / 217]$} & \multicolumn{8}{|c|}{ Highlighted: None } \\
\hline
\end{tabular}




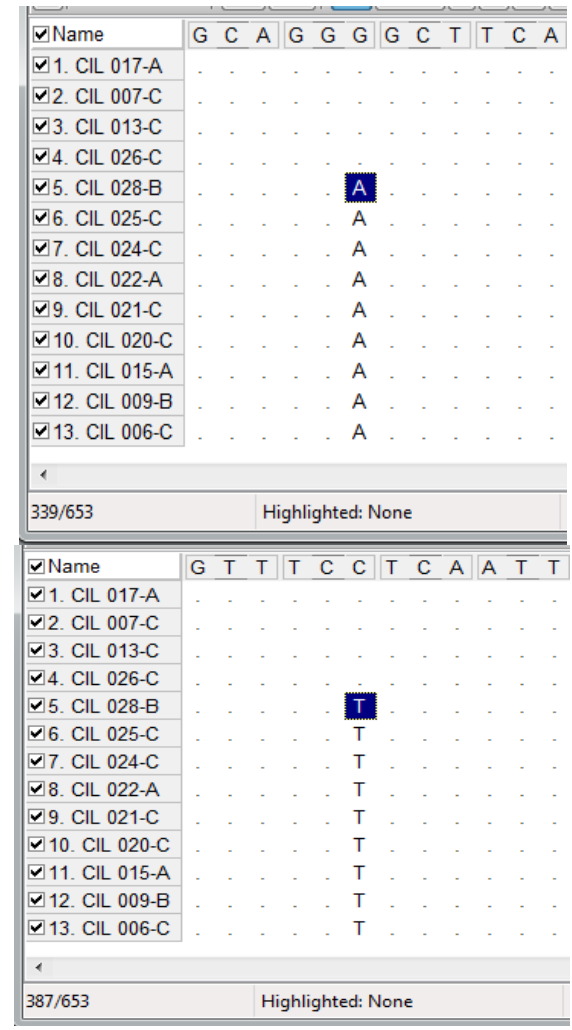

\begin{tabular}{|c|c|c|c|c|c|c|c|c|}
\hline \multicolumn{9}{|l|}{$\checkmark$ Name } \\
\hline$\checkmark 1$. CIL 017-A & $\mathrm{H}$ & A & $\mathrm{G}$ & A & $S$ & $\mathrm{~V}$ & D & L \\
\hline レ2. CIL 007-C & $\mathrm{H}$ & A & G & A & $\mathrm{s}$ & $\mathrm{V}$ & D & L \\
\hline च3. CIL 013-C & $\mathrm{H}$ & A & G & A & $\mathrm{s}$ & $\mathrm{V}$ & D & L \\
\hline$\checkmark 4 . \mathrm{CIL} 026-\mathrm{C}$ & $\mathrm{H}$ & A & G & A & $S$ & V & D & L \\
\hline マ5. CIL 028-B & $\mathrm{H}$ & A & $G$ & A & $S$ & V & D & L \\
\hline च6. CIL 025-C & $\mathrm{H}$ & A & G & A & $\mathrm{s}$ & $\mathrm{V}$ & D & $\mathrm{L}$ \\
\hline レ7. CIL 024-C & $\mathrm{H}$ & A & G & A & $\mathrm{s}$ & $\mathrm{V}$ & D & L \\
\hline$\checkmark 8$. CIL 022-A & $\mathrm{H}$ & A & G & A & $S$ & V & D & L \\
\hline$\checkmark 9 . \mathrm{CIL} 021-\mathrm{C}$ & $\mathrm{H}$ & A & G & A & $S$ & v & D & L \\
\hline$\checkmark 10 . \mathrm{CIL} 020-\mathrm{C}$ & $\mathrm{H}$ & A & G & A & $S$ & V & D & L \\
\hline$\checkmark 11 . \mathrm{CIL}$ 015-A & $\mathrm{H}$ & A & G & A & $S$ & V & $\mathrm{D}$ & L \\
\hline$\checkmark 12 . \mathrm{CIL} 009-\mathrm{B}$ & $\mathrm{H}$ & A & G & A & $S$ & V & D & L \\
\hline$\checkmark 13 . \mathrm{CIL} 006-\mathrm{C}$ & $\mathrm{H}$ & A & G & A & S & V & D & $\mathrm{L}$ \\
\hline \multicolumn{9}{|l|}{1} \\
\hline \multicolumn{3}{|c|}{$337,338,339[113 / 217]$} & & & & & & \\
\hline
\end{tabular}

\begin{tabular}{|c|c|c|c|c|c|c|c|c|c|c|}
\hline \multirow{2}{*}{$\begin{array}{l}\square \text { Name } \\
\square 1 . \mathrm{ClL} \text { 017-A }\end{array}$} & \multirow[b]{2}{*}{ A } & \multirow[b]{2}{*}{ G } & \multirow[b]{2}{*}{ v } & \multirow[b]{2}{*}{ S } & \multirow[b]{2}{*}{ is } & \multirow[b]{2}{*}{1} & \multirow[b]{2}{*}{$\mathrm{L}$} & \multirow[b]{2}{*}{ G } & \multirow[b]{2}{*}{ A } & \\
\hline & & & & & & & & & & \\
\hline च2. CIL 007-C & A & G & V & s & s & 1 & L & G & A & 1 \\
\hline च3. CIL 013-C & A & G & V & s & $\mathrm{s}$ & 1 & L & G & A & I \\
\hline$\checkmark 4 . \mathrm{CIL} 026-\mathrm{C}$ & A & G & V & $\mathrm{s}$ & $\mathrm{s}$ & 1 & L & G & A & I \\
\hline च5. CIL 028-B & A & G & V & s & $\mathrm{s}$ & 1 & L & G & A & 1 \\
\hline च6. CIL 025-C & A & G & V & $s$ & $\mathrm{~s}$ & 1 & L & G & A & 1 \\
\hline च7. CIL 024-C & A & G & V & $s$ & $\mathrm{~s}$ & 1 & L & G & A & 1 \\
\hline -8. CIL 022-A & A & G & V & s & $s$ & 1 & $\mathrm{~L}$ & G & A & 1 \\
\hline च9. CIL 021-C & A & G & V & $\mathrm{s}$ & $\mathrm{s}$ & 1 & L & G & A & I \\
\hline$\checkmark 10 . \mathrm{CIL} 020-\mathrm{C}$ & A & G & V & s & $\mathrm{s}$ & 1 & $\mathrm{~L}$ & G & A & I \\
\hline$\checkmark 11$. CIL 015-A & A & G & V & s & $s$ & 1 & L & G & A & I \\
\hline$\checkmark 12$. CIL 009-B & A & G & V & $s$ & $\mathrm{~s}$ & 1 & L & G & A & I \\
\hline -13. CIL 006-C & A & G & V & $\mathrm{s}$ & $\mathrm{s}$ & 1 & L & G & A & 1 \\
\hline \multicolumn{11}{|l|}{1} \\
\hline \multicolumn{3}{|c|}{$385,386,387[129 / 217]$} & & & & & Jone & & & \\
\hline
\end{tabular}

\begin{tabular}{|c|c|c|c|c|c|c|c|c|c|c|c|c|}
\hline$\nabla$ Name & A & T & T & T & G & $\mathrm{T}$ & G & T & G & G & & C \\
\hline$\checkmark 1 . \mathrm{CIL}$ 017-A & - & & . & & & & & . & & & . & \\
\hline$\checkmark 2 . \mathrm{CIL} 007-\mathrm{C}$ & . & & & & . & . & . & & & & & - \\
\hline 、3. CIL 013-C & . & & & . & . & & . & . & & & . & . \\
\hline V4. CIL 026-C & . & & . & & & & & & & & & \\
\hline \5. CIL 028-B & . & & . & C & & & & & & & & \\
\hline च6. CIL 025-C & . & & . & C & & & & & & & & \\
\hline จ7. CIL 024-C & . & & . & c & & & & & & & & \\
\hline 『8. CIL 022-A & . & & . & C & & & & & & & & \\
\hline 『9. CIL 021-C & . & & . & C & & & & & & & & \\
\hline$\checkmark 10 . \mathrm{CIL} 020-\mathrm{C}$ & - & & . & C & . & . & . & . & & & & . \\
\hline$\checkmark 11 . \mathrm{CIL} 015-\mathrm{A}$ & . & & . & c & . & . & . & & & & & . \\
\hline$\checkmark 12 . \mathrm{CIL} 009-\mathrm{B}$ & . & & . & C & & & & . & & & & \\
\hline$\checkmark 13 . \mathrm{CIL} 006-\mathrm{C}$ & . & & - & C & & & & & & & & \\
\hline \multicolumn{13}{|l|}{1} \\
\hline $471 / 653$ & & & & & ghte & $\mathrm{d}: \mathrm{N}$ & lone & & & & & \\
\hline
\end{tabular}

\begin{tabular}{|c|c|c|c|c|c|c|c|c|c|c|}
\hline \multirow{2}{*}{$\begin{array}{l}\text {-Name } \\
\square 1 . \mathrm{ClL} \text { 017-A }\end{array}$} & \multirow[b]{2}{*}{ T } & \multirow[b]{2}{*}{$\mathrm{P}$} & \multirow[b]{2}{*}{$\mathrm{L}$} & & \multirow[b]{2}{*}{ I V } & \multirow[b]{2}{*}{ w } & & \multirow[b]{2}{*}{ v } & \multirow[b]{2}{*}{$\mathrm{L}$} & \\
\hline & & & & $\mathrm{F}$ & & & & & & \\
\hline$\square 2 . \mathrm{CIL} \mathrm{007-C}$ & $\mathrm{T}$ & $\mathrm{P}$ & $\mathrm{L}$ & $\mathrm{F}$ & $\mathrm{v}$ & w & A & $\mathrm{v}$ & L & 1 \\
\hline - 3. CIL 013-C & $\mathrm{T}$ & $\mathrm{P}$ & $\mathrm{L}$ & $\mathrm{F}$ & $\mathrm{v}$ & w & A & $\mathrm{v}$ & L & 1 \\
\hline$\checkmark 4 . \mathrm{CIL} 026-\mathrm{C}$ & $\mathrm{T}$ & $\mathrm{P}$ & $\mathrm{L}$ & $\mathrm{F}$ & $\mathrm{v}$ & w & A & $\mathrm{v}$ & $\mathrm{L}$ & I \\
\hline च5. CIL 028-B & $\mathrm{T}$ & $\mathrm{P}$ & $\mathrm{L}$ & $\mathrm{F}$ & $\mathrm{v}$ & w & A & $\mathrm{v}$ & $\mathrm{L}$ & 1 \\
\hline$\checkmark 6$. CIL 025-C & $\mathrm{T}$ & $\mathrm{P}$ & $\mathrm{L}$ & $\mathrm{F}$ & $\mathrm{v}$ & w & A & $\mathrm{v}$ & $\mathrm{L}$ & $\mathrm{I}$ \\
\hline$\checkmark 7$. CIL 024-C & $\mathrm{T}$ & $\mathrm{P}$ & $\mathrm{L}$ & $\mathrm{F}$ & $\mathrm{v}$ & w & A & $\mathrm{v}$ & $\mathrm{L}$ & I \\
\hline$\checkmark 8 . \mathrm{CIL} 022-\mathrm{A}$ & $\mathrm{T}$ & $\mathrm{P}$ & L & $\mathrm{F}$ & $\mathrm{v}$ & w & A & $\mathrm{v}$ & L & 1 \\
\hline$\checkmark 9 . \mathrm{CIL} \mathrm{021-C}$ & T & $\mathrm{P}$ & $\mathrm{L}$ & $\mathrm{F}$ & $\mathrm{v}$ & w & A & $\mathrm{v}$ & L & I \\
\hline$\checkmark 10 . \mathrm{CIL} 020-\mathrm{C}$ & T & $\mathrm{P}$ & L & $\mathrm{F}$ & $\mathrm{v}$ & w & A & $\mathrm{v}$ & L & I \\
\hline V11. CIL 015-A & T & $\mathrm{P}$ & $\mathrm{L}$ & $\mathrm{F}$ & $\mathrm{v}$ & w & A & $\mathrm{v}$ & L & I \\
\hline V12. CIL 009-B & T & $\mathrm{P}$ & $\mathrm{L}$ & $\mathrm{F}$ & $\mathrm{v}$ & w & A & $\mathrm{V}$ & L & I \\
\hline$\checkmark 13 . \mathrm{ClL} 006-\mathrm{C}$ & $\mathrm{T}$ & $\mathrm{P}$ & $\mathrm{L}$ & $\mathrm{F}$ & v & w & A & v & L & I \\
\hline \multicolumn{11}{|l|}{1} \\
\hline \multicolumn{3}{|c|}{$469,470,471[157 / 217]$} & \multicolumn{7}{|c|}{ Highlighted: None } & \\
\hline
\end{tabular}

\section{References:-}

1. Aryahiyyah I. 2014. Verifikasi metode ekstraksi fenol kloroform untuk isolasi DNA pada daging dan produk olahan. [Skripsi]. IPB: Bogor.

2. Bijukumar A, Smrithy R, SureshkumarU, George S. 2015. Journal Of Threatened Taxa. 7 : 6987- 6995.

3. Campbell NA, Reece JB, Cain $\mu$ L, Wasserman SA, Minorsky PV, and Jackson RB. 2008. Biologi edisi kedepalan jilid 1. Jakarta:Erlangga.Chavez JM, Dela paz RM, Manohar SK, Pagulayan RC, Carandang VI JR. 2006.

4. New Philippine record of South American sailfin catfishes (Pisces: Loricariidae). Zootaxa. 1109: 57-68.

5. Dharmayanti NLPI. 2011. Filogenetika molekuler: metode taksonomi organisme berdasarkan sejarah evolusi. Wartazoa. 21: 1-10.

6. Hadiaty RK. 2007. Kajian ilmiah ikan Gar, Famili Lepisosteidae (Lepisosteus spp. \& Atractosteus spp.): Spesies ancaman bagi ikan asli Indonesia. Fauna Tropika. 16 : 87-96.

7. Hadiaty RK. 2011. Diversitas dan hilangnya jenis-jenis ikan di Sungai Ciliwung dan Sungai Cisadane. Berita Biologi.10 : 491- 504. 
8. Hajibabaei M and McKenna C. 2012. DNA mini-barcode. Springer science. 858: 339-353.

9. Hajibabaei M, Singer G, Elizabeth C, Paul D. 2007. Design and applicability of DNA barcodes in biodiversity monitoring. J BMC Biol. 5:1-7.

10. Hajibabaei M, Smith MA, Janzen DH, Rodriguez JJ, Whitfield JB, Hebert PDN. 2006. A minimalist barcode can identify a specimen whose DNA is degreded. Molecular Ecology Notes. 4: 959-964.

11. Hebert N, Hanner R, Holm E, Nicholas EE, Taylor E, Burridge M, Watkinson D, Dumon P, Curry A, Bentzen P, Zhang, April J, Bernatchez. 2004. Identifying candian freshwater fishes through DNA barcodes. J. Plos one. 3: 174-180.

12. Hubert PD, Cywinska A, Ball S. 2003. Biological indentification trough DNA barcodes. The Royal Societi Lond. 27: 313-321.

13. Jumawan JC, Vallejo BM, Herrera AA, Buerano CC, Fontanilla IKC. 2011. DNA barcodes of the suckermouth sailfin catfish Pterygoplichthys (Siluriformes: Loricariidae) in Marikina River system, Philippines: Molecular perspective of an invasive alien fish species. Philippine Science Leetters. 2 : 103-113.

14. Kusumah RV. 2011. Introduksi spesies asing, apakah mengancam kelestarian ikan-ikan Ciliwung. Balai Perikanan Budidaya Air Tawar.Bogor.

15. Lynch M and Jarrell PE. 1993. A method for calibrating moleculer clocks and its application to animal mitochondrial DNA. Genetics. 135: 1197-1208.

16. Mahardika IGNK dan Parede L. 2008. Analisi filogenetik sekuen nukleotida bagian hipervariabel protein VP2 virus gumboro isolat Indonesia. Veteriner. 9: 60-64.

17. Maramis RTD \& Warouw V. 2014. Karakteristik DNA CO1 serangga laut gerridae yang berasal dari Pantai Mokupa Sulawesi Utara. Jurnal Pesisir dan Laut Tropis. 1: 1-7.

18. Newson. 2013. ANOVA SPSS example. Spring. USP 634: 1-2

19. Nico LG, Butt PL, Johnston GR, Jelks HL, Kail M, Walsh SJ. 2012. Discovery of South American armored catfish (Loricariidae, Pterygoplichthys spp.) in The Santa Fe River drainage, Suwannee River Basin, USA. BioInvasions Record. 3 :179-200.

20. Rachmatika I dan Wahyudewantoro G. 2006. Jenis-jenis ikan introduksi di perairan tawar Jawa Barat dan Banten: Catatan tentang taksonomi dan distribusinya. Jurnal Ikhtiologi Indonesia. 6 : 93-97.

21. Rahardjo MF, Sjafei DS, Affandi R, Sulistiono, Hutaharat J. 2010. Iktiology bringing native fish back to The Rivers. Lubuk Agung: Bandung.

22. Ratmini NA. 2009. Kandungan logam berat Timbal (Pb), Mercuri (Hg) dan Cadmium (Cd) pada daging ikan sapu-sapu (Hyposarcus pardalis) di Sungai Ciliwung Stasiun Srengseng, Condet, dan Manggarai. VIS VITALIS. $2: 1-7$.

23. Sambrook J, Russel D W. 2001. Molecular cloning: A Laboratory manual 3rd edition. New York (USA) : Cold Spring Harbor.

24. Singkam AR, Solihin DD, Affandi R. 2011. Keragaman morfometrik dan gen Cytochrom b DNA mitokondria Krytopterus limpok di Sungai Batang Hari. Prosiding Forum Nasional Pemacuan Sumber Daya Ikan.

25. Tiara SN, Arziani AK, Siti NY, Aprilia EW, Retalia SS, Yunus DW, Sapta MJ, Huda AN, Alkahfi M. 2014. Isolasi dan kuantifikasi RNA pada Organ Usus Ikan Betok (Anabas testuneus) dengan Menggunakan Metode Isogen/ Genezol. IPB:Bogor.

26. Ubaidilah R dan Sutrisno H. 2009. Pengantar biosistematika (teori dan praktek).Museum Zoologi Bogoriensis. LIPI. 198.

27. Ward RD, Hanner R, Herbert DN. 2009. Review paper the campaign to DNA barcode all fishes, FISH-BOL. $J$ fish biol. 74:329-356.

28. Ward RD, Zemplak TS, Innes BH, Last PR, Hebert PDN. 2005. DNA barcodingAustralia's fish species. Philos Trans R soc Land B Biol Sci. 360 : 1847-1857.

29. Wardani AK dan Sari EPK. 2015. Deteksi molekuler cemaran daging babi pada bakso sapi di pasar tradisional Kota Malang menggunakan PCR (Polymerase Chain Reaction). Jurnal pangan dan agroindustri. 3 : $1294-1301$.

30. Widowati EW. 2013. Desain primer sitokrom b (Cyt b) sebagai salah satu komponen Polymerase Chain Reaction (PCR) untuk deteksi babi. Lembaga Penelitian UIN. Yogyakarta.

31. Wowor D. 2010. Studi biota perairan dan herpetofauna di Daerah Aliran Sungai (DAS) Ciliwung dan Cisadane: Kajian Hilangnya Keanekaragaman Hayati. LIPI:Cibinong.

32. Wu LW, Liu CC, Lin SM. 2011. Identification of sailfish catfish spesies (Pterygoplichthys, Loricariidae) in Taiwan based on morphology and mtDNA sequences. Zoological Studies. 50 : 235-246.

33. Yu SCS dan Quilang JP. 2014. Molecular phylogeny of catfish (Teleostei:Siluriformes) in The Philippine using the mitochondrial genes CO1, Cyt b, 16S rRNA, and the Nuclear Genes Rag1 and Rag2. Philippine journal of Science. 143. [2]:187-198. 